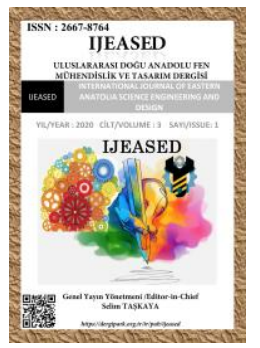

IJEASED INTERNATIONAL JOURNAL OF EASTERN ANATOLIA

Uluslararası Doğu Anadolu Fen Mühendislik ve Tasarım Dergisi ISSN: 2667-8764, 3(1), 257-281, 2021

https://dergipark.org.tr/tr/pub/ijeased

Araştırma Makalesi / Research Article

Doi: $\underline{10.47898 / \text { ijeased.868113 }}$

\title{
Karar Teorisinin Tarım Sektöründe Uygulanması
}

\author{
Burcu ÖZCAN ${ }^{1 a^{*}}$, Erdoğan Hakkı ÖZER ${ }^{1 b}$
}

${ }^{1}$ Kocaeli Üniversitesi, Mühendislik Fakültesi, Endüstri Mühendisliği, Kocaeli, 41000, Türkiye

\begin{tabular}{l|l|l}
\hline \multicolumn{1}{c|}{ Yazar Kimliği / Author ID (ORCID Number) } & \multicolumn{3}{|c}{ Makale Süreci / Article Process } \\
\hline "Sorumlu Yazar / Corresponding author : & Geliş Tarihi / Received Date $:$ & 25.01 .2020 \\
burcu.ozcan@kocaeli.edu.tr & Revizyon Tarihi / Revision Date : & 13.03 .2021 \\
\hline iD https://orcid.org/0000-0003-0820-4238, B. Özcan & Kabul Tarihi / Accepted Date : & 03.04 .2021 \\
iD https://orcid.org/0000-0002-8617-3791, E.H. Özer & Yayım Tarihi / Published Date : & 15.07 .2021 \\
\hline
\end{tabular}

Alıntı / Cite : Özcan, B., Özer, E.H. (2021). Karar Teorisinin Tarım Sektöründe Uygulanması, Uluslararası Doğu Anadolu Fen Mühendislik ve Tasarım Dergisi, 3(1), 257-281.

\section{Özet}

Karar analizi, karşılaşılan problemleri dikkate alarak çeşitli ölçütler sunmakta ve değerlendirme firsatı sağlamaktadır. Tarım sektöründe karşılaşılacak problemlerin belirsizlik ve risk taşıması karar analizinin sektörde kullanılmasını sağlamıştır. Bu çalışmada Tekirdağ'ın Şarköy ilçesinde tarım işleri ile uğraşan çiftçinin arazisinde yapacağı faaliyete karar verme aşamasında karar analizi çalışması yapılmıştır. Çalışmada yer alan durumlar belirsizlik ve risk altında değerlendirilmiş ve karar ağacı çizilerek sonuçlar yorumlanmıştır. Çalışmanın amacı çiftçiye belirlenen karar durumlarına bağlı olarak uygun olan seçeneği sunmak ve karar analizini tarım sektöründe uygulamaktır. Araştırma için gerekli bilgilere konu ile ilgili bilgi sahibi kişi ile yapılan görüşme yoluyla ulaşılmıştır. Ulaşılan verilerin analizi sonucunda belirsizlik ve risk altında değerlendirilmiştir. Veriler aracılığı ile çizilen karar ağacında olasılıklar iki farklı yol ile bulunmuştur. Karar ağacında olasılıkların atanma yolu değişmesine rağmen her iki durumda da seçilmesi uygun olan faaliyetin zeytin olduğuna karar verilmiştir.

Anahtar Kelimeler: Karar Analizi, Risk Altında Karar Verme, Belirsizlik Altında Karar Verme, Karar Ağacı.

\section{Decision Theory Implementation in Agricultural Sector}

\begin{abstract}
Decision analysis, offers various criteria by considering the problems encountered and provides an opportunity to evaluate. The uncertainty and risk of the problems to be faced in the agricultural sector enabled the decision analysis to be Used in this sector. In this study, a decision analysis study was carried out in the decision making phase of the activity
\end{abstract}


Özcan, B., Özer, E.H., Uluslararası Doğu Anadolu Fen Mühendislik ve Tasarım Dergisi / International Journal of Eastern Anatolia Science Engineering and Design (IJEASED)

(2021) 3(1):257-281

of the farmer Engaged in Agricultural Works in the district of Şarköy in Tekirdăg. The situations in the study were evaluated under uncertainty and risk and the decision tree was drawn and the results were interpreted. The aim of the study is to provide the farmer with the option that makes sense based on the determined decision situations and to apply the decision analysis in the Agricultural sector. The information required for the research was obtained through the interview with the person who has knowledge about the subject. As a result of the analysis of the data obtainde, it was evaluated under uncertainty and risk. In the decision tree drawn through the data, the possibilities were found in two different ways. Although the way of assigning possibilities changes in the decision tree, it is decided that the activity that makes sense in both cases is olive.

Keywords: Decision Analysis, Decision Making Under Uncertainty, Decision Making Under Risk, Decision Tree.

\section{Giriş}

Tarım sektörü, çeşitli besin maddelerini üretmekte olan, üretilen ürünleri farklılaştıran, kişilerin bu ürünlere olan gereksinimlerini gideren bundan dolayı toplulukların yaşamı ve geçimi üzerinde derin değişim ve gelişimlere yol açan bir sektördür (Arslan ve ark., 2015). Dünya üzerinde tarım sektörüne yapılan yatırımlar her ne kadar sanayi ve hizmet sektörüne yapılan yatırımlara göre az olsa da gelişmekte olan ve gelişmemiş olan ülkeler için önemli bir ekonomik sektördür. Gelişmiş ülkelerde ise sanayi ve hizmet sektörünün önemli bir ekonomik getiri oluşturduğu aşikardır. Tarım sektörüne yönelim gelişmiş ülkelerde diğer sektörlere göre az olsa da daha dikkatli bakacak olursak bu ülkelerde sektöre yapılan yatırımların daha dikkatli ve gerekli araştırmalar sonucu yapılması gerektirdiğini gözler önüne sermiştir. Tarım sektöründe belirsiz ve risk oluşturan problemlerin ve koşulların varlığı sektörde karşılaşılan herhangi bir soruna karşı uygulanacak stratejilerin geliştirilmesi, uygulama sürecinde karar seçeneklerinin tercihi gibi konularda karar analizinin önemini ortaya çıkarmaktadır. Türkiye odaklı bakıldığında ise tarım sektörü önemli bir konumda olmak ile beraber ihracat tabanlı sektör irdelendiğinde Tarım ve Orman Bakanlığ 2018 verilerine göre 360 milyon \$ organik ürün ihracatı yapıldı̆̆ı görülmektedir.

Tarım sektöründeki belirsizlik ve risk durumları sektörün doğaya bağımlılığından kaynaklanmaktadır. Günümüzde sanayinin bu kadar önemli bir boyuta ulaşması ve fabrikaların oluşturduğu doğa düşmanı atıklar ve gazlar sebebiyle doğaya karşı bir savaş söz konusudur. Doğanın bu denli harcanması ve tahrip edilmesi tarım yapılan arazilerin ve tarım ürünlerinin gelişimine katkı sağlayan bakteri ve bitkilerin zarar görmesine hatta doğada izlerinin kaybolmasına yol açmaktadır. Bunun sonucunda tarım sektöründe uygulanacak olan yöntemler ve üretilecek olan ürünlerin seçiminde ve sonuçlarının ne olacağı ile ilgili belirsizlikler ve riskler belirmektedir.

Sanayi, hizmet ve turizm sektörü başta olmak üzere pek çok sektörde herhangi bir yatırım alanına yönelecek olduğu zaman pek çok karar analizi yöntemi kullanılmaktadır. İnsanoğlunun tarihsel serüveninde önemli bir yeri olan ve sürekli yenilenen faaliyet olarak karar verme, karar 
vericilerin belirli seçenekleri belli faktörlere göre bir seçim, sıralama ya da sınıflandırma yapma gibi problemleri araştırma ve sonuçlandırma süreci olarak ifade edilmektedir. Karar verici, kişi veya işletme olarak hedeflerini eş zamanlı optimum düzeye çıkarmaya çalışarak zaman ve maliyet unsurlarını en düşük düzeye çekmeye çalışandır. Rekabetçi piyasaya göre işletmelerin işletmenin kuruluşundan, fonksiyonlarını yerine getirdiği döneme üstelik batışına kadar olan tüm aşamaları karar verme süreçlerinin ürünlerindendir (Bulğurcu ve Düzakın, 2011). Tüm bu karar verme süreçleri belirsizlik ve risk durumlarını içermektedirler. Tarım sektöründe de belli verilerin toplanması ve analizinden sonra karar verici karar analizi metotlarını kullanarak yatırım alanlarına yönelmesi sonucu hangi sonuçlar ile karşılaşacağını öngörme yoluna gidebilir. Karar verici pek çok koşul altında belirli veya belirsiz durumlar karşısında karar vermek zorunda kalabilmektedir. Bu durumlar göz önüne alındığında karar verici karşılaşması muhtemel olaylar karşısında hangi karar seçeneğine yöneleceğini tahmin etme gibi nitel analizler gibi karar analizi gibi sayısal verilere dayanan nicel analizlere de başvurabilmektedir.

Trakya bölgesinde Akdeniz ve Karasal iklimin belirli aralıklarla görülmesi, canlı çeşitliliğin var olması ve tarımın bölgede önemli bir konumda yer alması bu risk ve belirsizlik koşullarını azaltmaktadır. Olumlu durumların varlığının yanında yine de bir belirsizlik ve risk durumu da söz konusudur. Bu çalışmada tarım işleri ile uğraşan bir çiftçinin karşılaşabileceği belirsizlik ve risk durumlarını dikkate alarak arazisinde hangi bitki türünü yetiştirme kararını alacağı yapılan araştırmalar ve ön raporlar doğrultusunda belirsizlik altında, risk atında ve ön raporlar yardımı ile karar ağaçları da oluşturularak karar verici olan çiftçiye bir fikir vermesi ve yöneleceği tarım ürününü seçmesine yardım etmesi için karar analizi yöntemleri kullanılmıştır. Karar analizinde kullanılan veriler çiftçiye sorularak ve gerekli araştırmalar yapılarak elde edilmiş ve analiz edilmiştir. Elde edilen veriler POM QM paket programı kullanılarak irdelenmiştir. Analizler sonucu ortaya çıkan sonuçlar çiftçiye bir fikir oluşturma amacındadır. Tekirdağ' 'n Şarköy ilçesinde çiftçilik ile uğraşan kişinin tarlasında yetiştireceği üründen hangisinin daha mantıklı olduğu ve bölge koşulları dikkate alınarak belirsizlik ve risk durumlarının analizini yapmak bu çalışmanın amaçlarıdır.

Karar analizi, karşılaşılan problemleri dikkate alarak çeşitli ölçütler sunar ve değerlendirme fırsatı sağlamaktadır. Tarım sektöründe karşılaşılacak problemlerin belirsizlik ve risk taşıması karar analizin bu sektörde kullanılmasını sağlamıştır. Bu çalışmada Tekirdağ'ın Şarköy ilçesinde tarım işleri ile uğraşan çiftçinin arazisinde yapacağı faaliyete karar verme aşamasında karar analizi çalışması yapılmıştır. Çalışmada yer alan durumlar belirsizlik ve risk altında değerlendirilmiş ve karar 
ağacı çizilerek sonuçlar yorumlanmıştır. Çalışmanın amacı çiftçiye belirlenen karar durumlarına bağlı olarak mantıklı olan seçeneği sunmak ve karar analizini tarım sektöründe uygulamaktır. Araştırma için gerekli bilgiler konu ile ilgili bilgi sahibi kişi ile yapılan görüşme yoluyla elde edilmiştir. Elde edilmiş olan verileri inceleme sonucunda belirsizlik ve risk altında değerlendirilmiştir. Veriler aracılı̆̆ı ile çizilen karar ağacında olasılıklar iki farklı yol ile bulunmuştur. Karar ağacında olasılıkların atanma yolu değişmesine rağmen her iki durumda da seçilmesi mantıklı olan faaliyetin zeytin olduğuna karar verilmiştir.

\subsection{Tarım Sektörü ve Karar Analizi}

Stratejik değeri sebebiyle tarım, her topluma özel sosyal ve ekonomik boyuta dayalı bir tarım politikası ile açıklanan ve güç edinen bir sektördür. Sektör içerisinde geçerli olan mantalite ve stratejilerde temel amaç, rekabetçi, yenilenebilir ve kalıcı bir tarım sektörünün meydana getirilmesidir. Türkiye'de bugüne değin görülen tarımsal faaliyetler ile üretim miktarının ve çeşitliliğin yükseltilmesi amaçlanırken, bu politikaların oluşturdukları mali yük ve hedef kitleye ulaşamaması gibi problemleri içermektedir (Çılbant ve ark., 2006). Tarım sektörü için en önemli sorunlardan biri de iklim değişikliğidir. İklim değişikliklerinin bir sonucu olarak atmosferin giderek 1sınması, mevsim sıcaklık değerlerinin değişkenlik göstermesi, mevsimlerin kayması tarım sektöründeki faaliyetleri etkileyen sorunlardandır. Belirtilen sorunlar gıda güvenliği, yükselme ve ihracat ve ithalat gibi konularda kendilerini göstermektedirler. İklim değişkenliği ve bu değişkenliğin tarımsal faaliyetler üstündeki etkilerine üretilecek çözümlerde, tüm devletler tarafindan ciddiye alınmalı ve bu sorunları azaltıcı çözümler geliştirilip uygulanmaya başlanmalıdır (Bayraç ve Doğan, 2016).

Tarım sektöründe bir diğer sorun teşkil eden faktör ise belirsizlik ve risk durumlarını barındırmasıdır. Sektör içerisinde gerçekleştirilen faaliyetlerin büyük bir çoğunluğu direkt olarak doğa koşullarına bağımlıdır. Bu durumda kontrol edilemeyen etkenler ortaya çıkmaktadır. Sektör içerisinde kendine yer edinen ve tarım işleri ile uğraşan kişiler yaşadıkları bölgenin iklim koşullarına uygun, sahip oldukları arazi özelliklerine ayak uydurabilecek faaliyetler seçmek zorundadırlar. Aksi taktirde çabalarının sonuçsuz kalma ve kazanç elde edememe gibi durumlar ile karşı karşıya kalabilirler. Piyasada kendini ileriye atmak isteyen ve gelecek adına planlama yapmanın gereklilik olduğuna inananlar ileriye dönük analiz yapmalıdır. Arazi işleri ile uğraşan kişiler arazinin geleceği hakkında karar vermek adına kullanılabilecek bir analiz türü olarak karar analizi dikkat çekmektedir. Karar verme toplumca algılanan biçimi kadar kolay bir aşama değildir. Karar, genellikle kişilerin 
herhangi bir duruma karşı karşısındaki alternatifler içinden yaptığı seçimler şeklinde gözükse de oldukça kapsamlı bir süreci ifade etmektedir. Bu sürecin gerçekleştiği en önemli yerlerden birisi de tarım sektörüdür. Sektör içerisinde karar verme; belirli hedeflere ulaşmak için gidilebilecek yollar, yardımcı elemanlar ve elde bulunan araçlar ile doğru tercih yapma işlem şeklinde tanımlanabilir. Karar problemleri kurumsal, stratejik, yönetsel ve operasyonel şekilde irdelenmektedir. Aynı zamanda modellenebilmekte ve kolayca çözümlemesi yapılabilmektedir (Baykoç ve Öz, 2004).

Tarım işletmeleri üretim ve planlama gibi süreçlerde risk ve belirsizlik koşullarında faaliyetlerini devam ettirmektir. Firmalar Pazar ve doğa koşulları gibi faktörlerin oluşturduğu riskler karşısında mücadele içindedir. Doğa koşullarından oluşan riskler üretimi etkilemekte ve planlama süreçlerini de etkilemektedir. Üretim ile alakalı diğer risk faktörleri arasından en önemli olanları hava koşulları, hastalık, böceklerin zararı ve üretim teknolojisidir. Pazarlama riski ise üretime bağlı olarak oluşan pazar ortamından kaynaklanmaktadır. Fiyat değişikliği ve üretilen ürünlerin satılamama riski piyasanın ortaya çıkarabileceği pazarlama riskidir. Bu belirsizlik ve riskler karar alma sürecini etkilemektedir (Miran ve Şahin, 2010). Karar teorisi tam bu noktada sektör faaliyetlerine uygun olarak sunmuş olduğu yöntemler ile karar vermeyi kolaylaştırmaktadır. Karar teorisi tarım sektöründe belirsizlik altında ve risk altında karar verme gibi yöntemlerin barındırdığı ölçütler sunmaktadır. Ayrıca oyun teorisi, Markov analizi, ön rapor ile karar verme gibi alternatif çözüm yolları da bulunmaktadır. Karar vericinin karşılaştığı problemin türüne göre karar analizi aşamasında karar teorisinin çözüm yolarından herhangi biri uygulanabilir.

Tarım sektöründe karşılaşılan sorunlar karşısında karar vermek karar vericileri zorlayabilmektedir. Bunun nedeni faaliyetlerin doğaya bağımlı olmakla birlikte içerisinde risk ve belirsizlikler barındırmasıdır. Karar analizi bu açıdan avantaj sağlamaktadır. Karar vericilerin analizleri doğru bir şekilde uygulaması ve yorumlaması analiz aşamasında oldukça önemlidir. Tarım sektöründe karşılaşılan durumlar ve sorunlar karşısında karar analizi sektöre faydalı ve sayısal ifade şekline çözümler sunması sebebiyle tercih edilen bir uygulamadır.

\section{Literatür Özeti}

Emel ve Taşkın (2005), Geçmişten bugüne teknolojik olarak birçok gelişme yaşanmış ve işletmeler veri yığınları oluşturmuşlardır. Pazarlama politikalarında karar verme durumunun yerinde ve zamanında verilmesi, bu verilerin en iyi doğru biçimde irdelenmesi ve anlamlılık kazanması ile sağlanabilir. Veri madenciliği ile tahmin modellerinin meydana getirilmesinde etkili ve sürekli 
Özcan, B., Özer, E.H., Uluslararası Doğu Anadolu Fen Mühendislik ve Tasarım Dergisi / International Journal of Eastern Anatolia Science Engineering and Design (IJEASED) (2021) 3(1):257-281

biçimde uygulanan araçlardan biri karar ağaçlarıdır. Bu çalışmada, konu edinilen perakende satış yapan firma için firmanın her müşterisine özgü geliştirilmiş satış faaliyetlerini kapsayan veri tabanından faydalanarak ayrıntılı ve göreceli ölçüm çıktılarını kapsayan bir satış analizi hedeflenmektedir.

Albayrak ve Yılmaz (2009), Veri madenciliği, verileri elde etmeden önce bilinmeyen anlamlı bilgileri tanımlama veya tahminleme metotlarını kapsamaktadır. Yapılan çalışmada, İMKB 100 endeksinde endüstri ve hizmet alanlarında yer alan 173 işletmenin 2004-2006 yıllarına ait yıllık mali bilgilerinden faydalanarak veri madenciliği metotlarından biri olan karar ağaçları kullanılmıştır. Belirlenen mali durumlar dikkate alınarak endüstri ve hizmet alanlarında rol oynayan işletmeleri birbirinden farklı kılan yönler belirlenmiştir.

Bulğurcu ve Düzakın (2011), Bu çalışmada Akdeniz Bölgesi’nin önemli tarım merkezlerinden biri olan Adana yöresine ait orta büyüklükteki bir arazi üzerinde 10 farklı ürünü doğal riskler altında üretmeyi düşünen bir tarım işçisinin süregelen ve geleneksel metotlar dışında belirsizlik ve risk koşularının var olduğu durumlarda tercih edilen karar verme yöntemleri yardımıyla tarım sektöründe karar verme süreçlerini belirtmektedir.

Ulusoy (2013), Bu çalışmada, karar ağaçları metotları ile Cumhuriyet Üniversitesi İktisadi ve İdari Bilimler Fakültesi öğrencilerinin bilgileri ile veri madenciliği uygulanmıştır. Öğrencilere ait verilerden faydalanarak, hem elde edilen verileri en iyi şekilde sınıflandıran karar ağaçlarına ait algoritma, hem de bu algoritmanın üreteceği sınıfların belirlenmesi için çalışmalar yapılmıştır. Yapılan çalışmada sonuç olarak öğrenci verilerini sınıflandırmak için en başarılı algoritma LAD Tree algoritması on dokuz farklı sınıf oluşturduğu sonucuna varılmıştır.

Ozcan ve Külahlı (2020), makalelerinde karar teorisi yaklaşımını kullanarak lastik sektöründe benzer bir çalışma yapmışlardır. Garanti süreci kapsamında arızalı lastikler için farklı ölçütler altında stratejik kararlar vermişlerdir.

Balçık ve Şahin'in (2013), makalelerinde ekonomik değerlendirme metotları, maliyet etkinliği analizi süreci, indirgeme, duyarlılık analizi, bütçe etki analizi ve karar analizi hakkında bilgilendirme yapılmış ve bu analizlerin boyutları araştırılmıştır.

Akçetin ve Çelik (2014) çalışmalarında istenmeyen elektronik postaların belirlenmesinde çeşitli veri madenciliği metotlarından karar ağacı algoritmalarını uygulamıştır. Bu algoritmaların performansları karşılaştırılarak doğrulukları açısından en iyisi tespit edilmiştir. Sınıflandırmadaki veriler Kaliforniya Üniversitesi makine öğrenimi veri setlerinden elde edilen 4601 tane elektronik postalar yardımı ile elde edilmiştir. 
Arslan, Berkman ve Doğan (2015), Günümüz şartlarında devletlerin kalkınması ve rekabet ortamında avantajlı konuma geçmesinde etkin bir görevi olan tarım sektörünün önemi, küreselleşen dünya ekonomisi, yükselen makine teknolojisi ve değişim hızı artan piyasa koşullarının da etkisiyle zaman geçtikçe anlaşılmakta ve giderek artmaktadır. Asya ve Avrupa arası bir köprü görevi olan Türkiye, konum itibari ile üç tarafı ticari değer olan Akdeniz, Ege ve Karadeniz ile kaplı olması, sınırları içerisinde yer alan nehirler, akarsular ve canlı çeşitliliği sayesinde bitki, hayvan türleri ve su ürünleri bakımından oldukça değerli bir konumda yer almaktadır. Çalışmada tarım sektörü incelenmiş olup tarımsal faaliyetlerin toplumların ekonomik kalkınması üzerindeki önemi ile sektörün karşılaştığg sorunlar ele alınmıştır.

Güzel ve Taş (2017), Bu çalışmada tersine lojistik uygulaması, tekstil sektörüne göre irdelenmektedir. Tekstil sektöründe tersine lojistik uygulamalarının Türkiye'de ne boyutta, hangi yöntemler ile uygulandığı, uygulamada atık türlerinin hangisinin kullanılıp kullanılmadığı incelenmektedir. Yapılan bilimsel araştırma ve konularında uzman kişilerin düşünceleri belirlenen faktörlerin AHP ve DEMATEL çok ölçütlü karar verme metotları kullanılarak önem sıralama sonuçlarına ulaşılmıştır.

Ceylan ve Sarı'nın (2017), çalışmalarında Konya ilinde Çok Ölçütlü Karar Analizleri ve Coğrafi Bilgi Sistemleri kullanılarak ideal olan arıcılık yerleri analizler sonucu belirlenmiştir. Yapılan uygunluk haritası ile mevcut arıların yerleştirildiği mekanlar birleştirilerek uygunluğu kullanılabilirlik ve güvenirlilik açılarından irdelenmiştir. Araştırmanın sonucunda tarımsal alanlar dışında \%82 oranı ile kesişme olduğu sonucuna varılmıştır.

Özcan ve Yılmazer (2020), çalışmalarında Demir Çelik Sektöründe faaliyet gösteren bir işletmede Toz Toplama, İş Gücü, Yatırım Esnasında Üretim Durumu, Maliyet, Ara Madde ve Enerji Kullanımı, Günlük Üretim Miktarı gibi kriterler açısından en uygun yatırım seçenekleri irdelenmiştir.

Bingöl, Değirmenci ve Sofuoğlu'nun (2017), çalışmalarının amacı Türkiye odaklı sosyal, teknik, ekonomik, çevresel ve politik ölçütleri bir arada toplayarak kanun ve bilimsel gerçekler dikkate alınarak yasalar değiştikçe kendini güncelleyecek bir karar verme mekanizması oluşturmaktır. Ölçütlerin ağırlık değerlerini atamak için, çiftli karşılaştırma tekniğine dayanan Analitik Hiyerarşi Süreci (AHP) metodu kullanılmıştır. Bu çalışma, rüzgâr enerji santrallerinin planlama sürecini iyileştiren ve süre bakımında indirgeyen, uygulanmakta olan kanun ve bilimsel çalışmalara dayalı uygunluk haritasını görselleştirmektedir. Sonuç olarak oluşturulan bu 
sayısallaştırılmış haritanın, proje geliştiricilerinin ve yatırımcıların yer seçimi ve değerlendirilmesi adımını iyileştireceği ve kolay hale getireceği sonucuna varılmıştır.

Mercan ve ark. (2017), çalışmaları karmaşık karar verme problemlerinin analiz ve çözümlenmesine kullanılmakta olan çok ölçütlü karar analizi teknikleri, birçok bağımsız unsurun dikkate alınarak en ideal kararın alınmasını sağlamaktadır. Mekânsal analiz ve veri görselleştirme için çeşitli opsiyonları ortaya koyan coğrafi bilgi sistemleri ise, karmaşık karar problemlerinin analizinde sınırlı bir etki alanı sunmaktadır. Bu sebeple belirlenen sorunların çözüm aşamasında CBS destekli çok ölçütlü karar analizi yöntemleri uygulanmıştır. Çalışmada, farklı sektörlerdeki karar analiz yöntemleri analiz edilmiştir. Çok Amaçlı Karar verme yöntemi ile ilgili uygulama ve araştırmalar irdelenmiştir.

\section{Materyal ve Metot}

Araştırmada kullanılan veriler çiftçi ile soru cevap şeklinde yapılan mülakat aracılığg ile belirlenmiştir. Karar verici olan çiftçi 12500 metrekare alanında bir tarım arazisine sahiptir. Tarım arazisi üzerinde hali hazırda zeytin ağaçları bulunmaktadır. Arazide yer alan zeytin ağaçlarının sayısı 350 olmakla birlikte arazi sahibi zeytin ağaçlarından her sene düzenli olarak mahsul üretmekte ve kazanç sağlamaktadır. Karar verici 20 yıllık sürecin kazanç olarak kendisine yaklaşık olarak ne kadar getireceği hakkında bir fikir sahibi olmak istemekte olup ceviz ve zeytin seçeneklerini 10 yıl değerlendirdikten sonra farklı karar seçeneklerini değerlendirme imkanına sahiptir.

\subsection{Araştırmanın Amacı}

Çalışmanın amacı, tarım işleri ile uğraşan bir çiftçinin sahip olduğu arazi üzerinde almak istediği kararları belirsizlik ve risk altında değerlendirmek ve 20 yıllık süre göz önüne alınmak üzere arazinin yer aldığı bölgenin coğrafi ve iklim özellikleri gibi hava koşullarının temelini oluşturan özellikleri dikkate alınarak iyi ve kötü hava koşullarına göre karar verici olan çiftçi tarafından belirlenmiş olan ceviz ve zeytin karar seçeneklerinden hangisinin daha kazançlı olduğu hakkında çiftçide bir fikir oluşturmak istenmesidir.

\subsection{Araştırmada Kullanılan Veriler}

Çiftçinin sahibi olduğu tarım arazisi üzerinde hangi ürünün yetiştirileceğine karar vermek adına bir karar ağacı oluşturulmuştur. Arazi alındıktan sonra arazi üzerinde hangi faaliyet yapılacağına 
karar verilecektir. Arazi tarım arazisidir ve arazi içine hali hazırda 350 ağaç zeytin bulunmaktadır. Araziyi alan kişi zeytin veya ceviz arasında bir seçim yapmak istemektedir. Bu problem 20 yıllık bir süreci kapsamaktadır. Araziyi alan kişi ilk olarak ceviz ve zeytin seçeneklerini 10 yıl değerlendirdikten sonra farklı karar seçeneklerini değerlendirme imkanına sahiptir.

\subsubsection{Zeytin ile ilgili veriler}

Oleaceae familyasında yer alan o zeytinin, isminin kökü Yunanca elaia, Latince olea'dan gelmiştir. Boyu 2 ile 10 metre arası değişiklik gösteren fakat 15 ile 20 metreye kadar büyüyebilen bitki türüdür. Meyveleri ilk olarak yeşildir, ekim-kasım aylarında morarmakta ve olgunlaşmaktadır. Genel olarak 300 ile 400 sene arası bir yaşam ömrüne sahip bir ağaç olan zeytin 2000 sene yaşayan örnekleri olması zeytinin susuzluktan etkilenmemesinin bir sonucudur (Arihan ve Kaplan, 2012). Zeytin yetiştiriciliği için $1 s ̧ 1 \mathrm{k}$, güneş, günlük ortalama $15{ }^{\circ} \mathrm{C}$ ve üzerindeki sıcaklık ile yıllık en az ortalama $220 \mathrm{~mm}$. yağış alan bölgeler idealdir (Çolakoğlu, 2009). Akdeniz iklimine sahip olan çoğu bölgede yetişen zeytin ağacı Marmara Bölgesi için tipik bir bitki türüdür. Arazi sahibi zeytinin bu özelliklerini de dikkate alarak araziyi daha önceden satın almıştır. Arazi satın alındığında içerisinde 350 ağaçlık zeytin bulunmaktadır. Araziyi satın alan kişi zeytin üretimi ile devam etmek isterse herhangi bir ön maliyet söz konusu olmayacaktır. Zeytin üretimi ile devam edilmek istenirse zeytinin yıllık mahsulü, fiyatları gibi kazanç değerleri zeytin yetiştiricisine danışarak belirlenmiştir. Tarım Kredi Kooperatifi'nden alınan bilgilere göre bir zeytin ağacı senede 25 ile 40 kilo arasında zeytin verebilmektedir. Senelik mahsulün yaklaşık \%25'i yağlı, geri kalanı ise sofralık olarak verilmektedir. Bir kilo sofralık zeytinin kooperatife satış fiyatı ortalama 10 €’dir. Yağlık zeytin için kooperatife kilo başına satış fiyatı 4 €'dir.

Zeytin seçeneği için olasılık durumları iyi hava koşulu ve kötü hava koşulu durumları bulunmaktadır. İyi hava koşullarında bir zeytin ağacının senelik 40 kilo ve kötü hava koşullarında ise 25 kilo vereceği varsayılmış, hesaplamalar bunun üzerine yapılmıştır. Bu varsayımlar 1şı̆̆ında zeytinden sağlanacak kazanç değerleri aşağıdaki gibidir.

İyi Hava Koşullarında (Sofralık): 350x40x10x (0.75) =105.000

İyi Hava Koşullarında (Yağlık):350x40x4x (0.25)=14.000

İyi Hava Koşullarında Toplam $=119.000 €$

Kötü Hava Koşullarında (Sofralık): 350x25x10x (0.75) =65.625 €

Kötü Hava Koşullarında (Yağl1k): 350x25x4x $(0,25)=8.750 €$

Kötü Hava Koşullarında Toplam: 74.375 € 
Araştırmada varılmak istenen nokta hangi tarım ürününün karar verici için daha mantıklı olduğunu ortaya çıkarmaktır. Bunun için oluşturulan karar ağacının karar düğümlerinden biri olan zeytin seçeneği ile ilgili bilgilere çiftçi ile soru cevap şeklinde yapılan mülakat ile ulaşılmıştır.

\subsubsection{Ceviz ile ilgili veriler}

Türkiye'de senelik ortalama 120.000 ton ceviz üretimi ile dünya ceviz üretimi açısından değerli bir konumdadır. Tümü tohumdan yetiştirilmiş ceviz popülasyonları içinde farklı 1slah amaçları açısından önemli ceviz gen kaynaklarının olduğu ülkemizde dört milyonun üstünde ceviz ağacı vardır. Avrupa ülkelerinde son senelerde ceviz yetiştiriciliğinin önemli bir konumda olması sebebiyle hem üretimde hem de ceviz ihracatında önemli gelişme ve değişimler gerçekleşmektedir (Akça ve Köroğlu, 2005). Ceviz bitki türünün ülke içerisindeki konumu ve yetiştiriciliği de günden güne artmaktadır. Tüm bu bulgular göz önüne alındığında karar verici ikinci karar seçeneği olarak ceviz seçeneğini düşünmüştür. Arazi üzerine ceviz ağacı dikilmek istenirse ilk olarak arazideki zeytinlerin sökülmesi gerekmektedir. Bu da ek bir maliyet oluşturacaktır. Ceviz ağaçları araziye 40 metrekarede bir ceviz ağacı olacak şekilde dikilecektir. Bunun sunucunda araziye toplam 300 ceviz ağacı dikmek planlanmıştır. Tarım Kredi Kooperatifi'nden alınan bilgilere göre bir ceviz ağacı senede 10 ile 20 kilo arasında ceviz vermektedir. Cevizin kilo başı fiyatı 25 €’dir. Arazideki zeytinler söküldükten sonra ceviz ağacı dikileceği için ilk 3 yıl meyve vermemektedir.

Ceviz ağacı için iyi hava koşulu ve kötü hava koşulu olma durumları söz konusudur. İyi hava koşullarında ceviz ağaçlarının senede 20 kilo, kötü hava koşullarında ise senede 10 kilo vereceği varsayılmış ve hesaplamalar buna göre yapılmıştır. Çiftçi eğer ceviz bitki türünü üretme kararı alırsa zeytin ağaçlarını arazi üzerinden sökmek zorunda kalacak ve ceviz ağaçlarını da en baştan ekmeye katlanma durumunda kalacaktır. Bu durumda ek maliyetleri de hesaba katmak zorunda olan karar verici ceviz bitki türünün meyve vermesi için 3 yıl mahsul alma süresi boyunca kazanç elde etmeme koşulunu da dikkate almak zorundadır. Ceviz ağacını ekme maliyetleri aşağıda yer almaktadır.

Fidan Maliyeti: $300 \times 20=6.000 €$

Bakım Maliyetleri: $3.000 \times 3=9.000 €$

Gübreleme ve İşçilik Maliyetleri: $3.000+2.000=5.000$ €

Ceviz ağacı için iyi hava koşulu ve kötü hava koşulu olma durumları söz konusudur. İyi hava koşullarında ceviz ağaçlarının senede 20 kilo, kötü hava koşullarında ise senede 10 kilo vereceği varsayılmış ve hesaplamalar buna göre yapılmıştır. Buna göre ceviz bitki türünü seçme durumunda elde edilecek kazanç bilgileri aşağıdaki gibidir. 
İyi Hava Koşullarında: 300x20x25=150.000

Kötü Hava Koşullarında: 300x10x25 = 75.000

Yapılan hesaplamalar sonucunda ceviz ekme işlemi için toplam 20.000 € maliyet ödenmek zorundadır. Kazanç durumları ise iyi hava koşullarında senede 150.000 モ, kötü hava koşullarında ise 75.000 ₹ olarak belirlenmiştir.

\subsubsection{Araziyi satın alma durumu ile ilgili veriler}

Araziyi satın alan kişi ceviz veya zeytin ekme durumunda 20 yıllık plan sonunda araziyi satma kararını verebilmektedir. Bunun sonucunda arazinin değeri bilinmek istenmektedir. Arazi 2014 yılında değer olarak metrekare başına 20 ile 30 € değeri bulunmaktadır. Arazi satın alındıktan sonra 5 sene geçmiş ve değeri yapılan araştırmalara göre metrekare başına 36 € olarak belirlenmiştir. Arazinin 20 y1l sonraki değeri ise arazinin 312.500 £'dan 450.000 €’ya 5 sene sonunda ulaşması dikkate alınarak her yıl değerine 17.500 € kattığı varsayılmıştır. Bunun sonucunda arazinin 20 yıl sonunda değeri 862.500 € olarak belirlenmiştir. Araziyi kiralama durumu da söz konusudur. Bu durumda arazi sahibi arazisini bir başka tarım işleri ile uğraşan kişiye kiralayarak yıllık kira alacaktır. Alacağı yıllık kiranın tutarı $25.000 €$ olarak belirlenmiştir.

\subsubsection{Karar durumları ile ilgili veriler}

Oluşturulan karar ağacında iyi ve kötü hava koşulları olmak üzere iki tane olay yani karar seçeneklerini etkileyeceği belirlenmiş olan karar durumları bulunmaktadır. Belirlenen karar durumları ilk olarak sezgisel olarak geçmiş tecrübe ve araştırma konusu olan tarım arazisinin yer aldığı bölge itibari ile iklim, toprak özellikleri gibi fiziksel özellikler incelenmiş ve bir olasılık değeri atanmıştır. Geçmiş deneyimlere göz önünde bulundurularak iyi hava koşullarına 0,80 ve kötü hava koşullarına ise 0,20 olasılıkları atanmıştır. Sezgisel olarak belirlenen olay olasılıklarının yanında araştırmanın daha sayısal verilere dayanması ve ikna edici olabilmesi açısından Tekirdağ ilinin 1938208 yılları arasında atlık sıcaklık ortalamaları dikkate alınmıştır. Aylık sıcaklık ortalamalarının ortalaması alınmış ve bu değerin altında kalan aylık sıcaklık ortalamaları kötü hava koşullarını, üstünde kalan aylık sıcaklık ortalamaları ise iyi hava koşullarını ifade edecek şekilde belirlenmiştir. 
Özcan, B., Özer, E.H., Uluslararası Doğu Anadolu Fen Mühendislik ve Tasarım Dergisi / International Journal of Eastern Anatolia Science Engineering and Design (IJEASED)

(2021) 3(1):257-281

Tablo 1. Tekirdağ ili 1938- 2018 yılları aylık ortalama sıcaklık ortalamaları (URL-1, 2020)

\begin{tabular}{|c|c|c|c|c|c|c|c|c|c|c|c|c|c|}
\hline TEKİRDAĞ & Ocak & Şubat & Mart & Nisan & Mayıs & Haziran & Temmuz & Ăgustos & Eylül & Ekim & Kasım & Aralık & Yıllık \\
\hline $\begin{array}{c}\text { Sicaklık } \\
\text { Ortalaması }\end{array}$ & 4,7 & 5,4 & 7,3 & 11,8 & 16,8 & 21,3 & 23,8 & 23,8 & 20 & 15,4 & 11 & 7,1 & 14 \\
\hline $\begin{array}{c}\text { En Yüksek } \\
\text { Sıcaklık } \\
\text { Ortalaması }\end{array}$ & 8 & 8,9 & 11 & 15,8 & 20,6 & 25,3 & 28 & 28,2 & 24,4 & 19,5 & 14,7 & 10,3 & 17,9 \\
\hline $\begin{array}{c}\text { En Düşük } \\
\text { Sıcaklık } \\
\text { Ortalaması }\end{array}$ & 1,9 & 2,4 & 4,1 & 8,1 & 12,7 & 16,6 & 19 & 19,3 & 16 & 12 & 8,1 & 4,2 & 10,4 \\
\hline
\end{tabular}

Tekirdağ ilinin 1938-2018 yılları arasında aylık ortalama sıcaklık değerleri Tablo 1'de yer almaktadır. Yıl bazında bakıldığı zaman ayların ortalama sıcaklığ $14{ }^{\circ} \mathrm{C}$ olarak belirlenmiştir. Bu değerin altındaki değerler kötü hava koşullarını, üstündeki değerler ise iyi hava koşullarını ifade etmektedir. Bu doğrultuda iyi hava koşulları \%50, kötü hava koşulları \%50 olarak belirlenmiştir. Beklenen değer hesaplamaları bulunan olasılık değerlerine göre yeniden yapılmıştır. Karar seçeneklerini etkileyen olayların gerçekleşme olasılıklılarının iki farklı şekilde atanması karar vericide ne gibi fikir değişimlerine neden olabileceği ve seçim alternatiflerinin değerlerinin neler olacağı açısından önemli bir kıstas olarak görülebilir.

\subsection{Araştırmanın Yöntemi}

Araştırma verileri bilgi alınacak olan kişi ile karşılıklı konuşmaya dayanan ve konuyu aydınlatmak üzere derinlemesine soru sorma olanağı veren görüşme tekniği ile elde edilmiştir. Araştırmada kullanılan verileri elde etmek amacıyla konu ile ilgili bilgi sahibi olan kişi ile soru cevap şeklinde bilgi almaya dayalı bir görüşme gerçekleştirilmiştir. Görüşme yapılan kişiye sorulan sorular önceden belirlenmiş ve direkt olarak verileri dolaysız yoldan elde etme yoluna gidilmiştir. Sorular oldukça açık ve net bir şekilde hazırlanmış ve görüşme yapılan kişinin yanlış bilgi vermemesi sağlanmıştır. Sorular 3 bölüme ayrılmıştır. Bölümlendirmede yer alan ana başlıklar karar seçenekleri ile ilgili sorular, karar durumları ile ilgili olan sorular ve tarım arazisi ile ilgili sorular şeklindedir. İlk bölümde karar seçeneklerinin neler olabileceği ve belirlenen karar seçeneklerinin sayısal verilerinin günümüz koşullarına ait verilerini, ikinci bölümde karar durumlarını içeren ve daha çok bölge iklimi ile ilgili sorular ve son bölümde ise arazi özellikleri ile ilgili sorular sorulmuştur.

Görüşme hem arazi, tarım işleri ve bölge iklim ve toprak özellikleri hakkında bilgi sahibi olan hem de karar seçeneklerini tarım arazisinin sahibi olması açısında arazi sahibi ile gerçekleştirilmiştir. Yapılan görüşmenin ilk bölümünde araştırmanın süresi, karar seçenekleri, durum tespitleri gibi konular irdelenmiştir. Bunun sonucunda sürecin 20 yılı kapsaması ve arazinin gelecekteki 
planlamasına dair zeytin, ceviz, satma ve kiralama işlemleri üzerinde durulmuştur. İkinci bölümde ise karar seçeneklerini etkileyen olaylar yani arazinin geleceğini hangi durumların etkileyebileceği üzerinde konuşulmuştur. Bu bölümde ise tarım faaliyetlerinin bağımlı olduğu ve planlamaların bu koşula bağlı olduğu için hava koşulları belirlenmiştir. Son bölümde ise arazinin kiralanması veya satın alması durumunda arazinin ederini oluşturacak olan arazi özellikleri, konumu ve alanı hakkında veriler toplanmıştır.

Görüşmeden elde edilen veriler yardımı ile ilk olarak belirsizlik altında daha sonra ise risk altında karar analizi uygulanmıştır. En son ise sürecin tamamını kapsayan ve karar verici olan arazi sahibinin stratejileri oluşturan bir karar ağacı oluşturulmuş̧tur. Karar ağacında karar düğümleri ve olay düğümleri ve olasılıklar şematik olarak yer almıştır. Karar vericinin gerçekleşmesini tahmin ettiği düşünceler karar ağacı aracılığı ile görselleştirilirmiş ve somut hale getirilmiştir. Bu aşamadan sonra karar ağacındaki stratejiler dikkate alınarak Beklenen Değer Analizi yapılmış ve her düğümün beklenen değeri hesaplanmıştır. Beklenen değer hesaplaması karar ağacında bastan sona doğru olacak şekilde yapılmıştır ve her düğümün beklenen değeri üzerinde gözükecek şekilde belirtilmiştir. Bu hesaplamalar karar analizi, yöneylem ve atama gibi konular ile ilgili pek çok probleme çözüm bulan ve kolaylık sağlayan POM QM paket programı kullanılarak yapılmıştır. Beklenen değer analizi hem sezgisel yöntemler ile belirlenmiş hem de sayısal verilere dayalı olarak atanan olay olasılıkları ile yapılmıştır. Bunun sonucunda beklenen değerler ve karar durumlarında ne gibi değişikliklerin olduğu gözlemlenmiştir.

\section{Bulgular}

Araştırmanın ana hedefi olan karar vericide bir fikir uyandırma çabası ile tarım arazisi ile hangi faaliyetin yapılacağı belirsizlik ve risk altında incelenmiştir.

Karar verme aşamasında belirsizlik ve risk altında karar analizi uygulaması olarak karar matrisleri önemli bir konumda yer almaktadır. Karar matrisleri oluşturularak karar vericinin karar seçenekleri, karar durumları ve koşullara bağlı kazanç veya maliyet değerleri açık bir şekilde görülmektedir. $\mathrm{Bu}$ aşamada belirsizlik altında karar analizi ve risk altında karar analizi ölçütlerini kullanmak üzere karar seçenekleri zeytin, ceviz ve araziyi kiralama belirlenmiştir. Olaylar ise iyi ve kötü hava koşulları belirlenmiş ve zeytinin iyi hava koşullarındaki kazancı 2.380.000 €, kötü hava koşullarında ise 1.487.500 ₹ olarak, cevizin iyi hava koşullarındaki kazancı 2.550.000 €, kötü hava koşullarında ise 1.275.000 $€$ olarak ve en son olarak ise kiralama seçeneğinin iyi hava koşullarında kazancı 500.000 € ve kötü hava koşullarında ise 200.000 ₹ olarak hesaplanmıştır. Karar 
seçeneklerinin olaylara göre getirdiği kazanç değerleri bölüm 3.2.1. ve 3.2.2.' de hesaplanmış olan verilerin 20 yıllık süreci dikkate alarak tekrardan hesaplanmış şeklidir. Oluşturulan karar matrisi tablo 2’ de daha anlaşılır bir şekilde görülmektedir.

Tablo 2. Belirsizlik altında karar matrisi

\begin{tabular}{lcc} 
& İyi Hava Durumu & Kötü Hava Durumu \\
\cline { 2 - 3 } Zeytin & $2.380 .000 €$ & $1.487 .500 €$ \\
Ceviz & $2.550 .000 €$ & $1.275 .000 €$ \\
Kiralama & $500.000 €$ & $200.000 €$
\end{tabular}

Tablo 2.' de belirsizlik altında karar vericinin karar seçeneklerini oluşturan zeytin, ceviz ve kiralama durumları ve olaylara göre kazanç değerleri açıkça belli olmaktadır. Belirsizlik altında oluşturulan karar matrisinde yer alan veriler aynı zamanda risk altında karar matrisinin de verilerini oluşturmaktadır. Belirsizlik altında karar analizinden farkı ise olayların olma olasılıklarının matriste yer almasıdır. Olayların gerçekleşme olasılıkları bölüm 3.2.3.’te belirtilmiştir.

\subsection{Belirsizlik Altında Karar Analizi}

Belirsizlik altında karar verme durumu karar seçeneklerini etkileyen karar durumları yani olayların gerçekleşme olasılıklarının belirlenmediği veya belirlenme imkanının olmadığı durumlarda analiz yapma olanağı sunan ve belirli birkaç ölçütü bulunan analiz sürecidir. Tablo 2.'de belirsizlik altında karar matrisi yer almaktadır.

Tablo 3. Belirsizlik altında karar verme ölçütleri ve sonuçları

\begin{tabular}{|c|c|c|c|}
\hline & İyimserlik & Kötümserlik & Pişmanlık \\
\hline Zeytin & 2.380 .000 三 & 1.487.500 & $170.000 €$ \\
\hline Ceviz & $2.550 .000 €$ & $1.275 .000 €$ & $212.500 €$ \\
\hline \multirow[t]{2}{*}{ Kiralama } & 500.000 き & $200.000 €$ & $2.050 .000 €$ \\
\hline & 2.550 .000 E & $1.487 .500 \mathrm{E}$ & $170.000 \mathrm{E}$ \\
\hline
\end{tabular}

Belirsizlik altında karar verme durumunda Tablo 3'te yer alan ölçütler kullanılmakta ve karar vericinin karar verme mantığına göre seçenekler sunmaktadır. Ölçütlere göre ortaya çıkan sonuçlar aşağıdaki gibidir.

Karar verici iyimser yaklaşıma sahip ise iyimserlik ölçütüne göre en fazla kazanç getiren yatırım 2.550.000 € kazanç değeri ile ceviz seçeneğine karar verilir 
Karar verici kötümser yaklaşıma sahip ve gelecekte ekonomik durumun kötüleşeceğini düşünen biri ise duruma kötümser yaklaşır. Yani seçeneklerin en az kazanç getiren değerlerini belirler ve bunlar arasından maksimum olanı seçer. Tablo 3'e göre bu seçenek 1.487 .500 € kazanç değeriyle zeytin seçeneğidir.

Pişmanlık ölçütünde ise sütün bazlı pişmanlık durumlarında kaybedilecek kazanç değerleri belirlenir. Pişmanlık ölçütünde pişmanlık miktarlarının en az yani minimum olanı seçilmektedir. Bu durumda 170.000 € pişmanlığa sahip olan zeytin seçeneği bu ölçüte göre seçilen seçenek olarak göze çarpmaktadır.

\subsection{Risk Altında Karar Verme}

Belirsizlik ve risk altında karar verme durumundan farklı olarak karar durumlarının gerçekleşme olasılıklarının belli olduğu ve hesaplamalara katıldığı karar verme analizidir. Araştırmanın bölüm 3.2.4. kısmında olayların olasılıkları ile ilgili 2 yaklaşımın varlığından bahsedilmişti. Olayların gerçekleşme olasılıkları ilk olarak geçmiş deneyim ve bölge özellikleri dikkate alınarak sezgisel olarak belirlenmiş ve iyi hava koşullarına 0,80 ve kötü hava koşullarına 0,20 olasılıkları atanmıştır. Daha sonra olasılıkların sayısal verilere dayanması amacıyla Tekirdağ ilinin 1938- 2018 yılları arasında aylık sıcaklık ortalamaları göz önünde bulundurularak iyi ve kötü hava koşullarında 0,50 olasılıkları atanmıştır. Bu aşamada risk altında karar verme durumunda olasılıkların belirlenme şekillerinin farklılığının karar seçenekleri üzerindeki etkileri incelenmiş ve farklılıklar belirlenmiştir.

Tablo 4. Olayların olasılıklarının sezgisel olarak belirlendiği risk altında karar matrisi

İyi Hava Durumu

Kötü Hava Durumu

\begin{tabular}{lcc}
\hline Olasilıklar & 0,8 & 0,2 \\
\hline Zeytin & $2.380 .000 €$ & $1.487 .500 €$ \\
Ceviz & $2.550 .000 €$ & $1.275 .000 €$ \\
Kiralama & $500.000 €$ & $200.000 €$
\end{tabular}

Tablo 4'te sezgisel olarak olayların olasılıklarının belirlendiği risk altında karar verme durumunda oluşturulan karar matrisi yer almaktadır. Karar matrisindeki değerler belirsizlik altında karar verme durumunda olduğu gibi POM QM paket programına girilmiş ve çözdürülmüştür.

Karar verici olan tarım arazisine sahip kişi zeytin, ceviz ve araziyi kiralama seçeneklerinden hangisinin daha mantıklı ve hangi ölçütlerde hangi kararların geçerli olabileceği gibi sonuçlar hakkında bilgilendirilmesi için risk altında karar analizi ölçütlerini POM QM programı sayesinde 
çözdürülmüştür. POM QM programında verilerin girilmesi ile risk altında karar verme durumunda kullanılan beklenen değer analiz, beklenen fırsat kaybı gibi ölçütler ile veriler irdelenmiş ve tam bilginin varlığı durumunda elde edilebilecek olan kazanç durumu çözüme kavuşmuştur. Tam bilginin varlığı durumunda elde edilen kazanç değeri sayesinde tam bilginin beklenen değeri de bulunmuştur.

Tablo 5'te görüldüğü üzere beklenen değer analizinde her karar seçeneği için gerçekleşmesi muhtemel olayların olasılıkları karar seçeneklerinin olaylara göre alacağı değerler ile çarpılmış ve çıkan sonuçlar toplanmıştır. Bu işlemler sonucunda zeytin için beklenen değer 2.201.500 beklenen değer 2.295.000 ₹ ve araziyi kiralama durumunda beklenen değer ise 440.00 ₹ sonucuna varılmıştır. Beklenen değer analizine göre mantıklı olan ve karar vericiyi avantajlı duruma getirecek olan kazancı daha fazla olan ceviz karar seçeneği göze çarpmaktadır. Bir diğer analiz ölçütlerinden biri olan beklenen firsat kaybına göre zeytin için 136.000 €, ceviz için 42.500 € ve kiralama seçeneği için 1.897.500 £ kayıp değerleridir.

Tablo 5. Sezgisel olarak belirlenen olasılıklı risk altında karar analizi sonuçları

Beklenen Değer Analizi

\begin{tabular}{lccc} 
& İyi Hava Koşulları & $\begin{array}{c}\text { Kötü Hava } \\
\text { Koşulları }\end{array}$ & Beklenen Değer \\
\hline Olasılıklar & 0,8 & 0,2 & \\
\hline Zeytin & $1.904 .000 €$ & $297.500 €$ & $2.201 .500 €$ \\
Ceviz & $2.040 .000 €$ & $250.000 €$ & $\underline{\mathbf{2 . 2 9 5 . 0 0 0}}$ \\
Kiralama & $400.000 €$ & $40.000 €$ & $440.000 €$
\end{tabular}

Beklenen Firsat Kaybı

\begin{tabular}{lccc} 
& İyi Hava Koșulları & $\begin{array}{c}\text { Kötü Hava } \\
\text { Koșulları }\end{array}$ & $\begin{array}{c}\text { Beklenen Fırsat } \\
\text { Kaybı }\end{array}$ \\
\hline Olasılıklar & 0,8 & 0,2 & \\
Zeytin & $170.000 €$ & $0 €$ & $136.000 €$ \\
Ceviz & $0 £$ & $212.500 €$ & $\underline{\mathbf{4 2 . 5 0 0 €}}$ \\
Kiralama & $2.050 .000 €$ & $1.287 .500 €$ & $1.897 .500 €$
\end{tabular}

Tam Bilginin Beklenen Değeri

\begin{tabular}{|c|c|c|c|}
\hline & İyi Hava Koșulları & $\begin{array}{c}\text { Kötü Hava } \\
\text { Koșulları }\end{array}$ & Toplam \\
\hline Olasılıklar & 0,8 & 0,2 & \\
\hline Zeytin & $2.380 .000 €$ & $1.487 .500 €$ & \\
\hline Ceviz & $2.550 .000 €$ & $1.275 .000 €$ & \\
\hline Kiralama & $500.000 €$ & $200.000 €$ & \\
\hline Tam Bilgi & $2.550 .000 €$ & $1.487 .500 €$ & \\
\hline
\end{tabular}




\begin{tabular}{|c|c|c|c|}
\hline $\begin{array}{c}\text { Tam Bilgi } \\
(\%)\end{array}$ & $2.040 .000 €$ & $297.500 €$ & $2.337 .500 €$ \\
\hline $\begin{array}{c}\text { Beklenen } \\
\text { Değer }\end{array}$ & & & $2.295 .000 €$ \\
\hline Tam Bilgini & & & \\
\hline $\begin{array}{c}\text { Beklenen } \\
\text { Değeri }\end{array}$ & & & $\underline{42.500 \mathrm{E}}$ \\
\hline
\end{tabular}

Tam bilginin beklenen değeri de risk altında karar analizinde elde edilen önemli çıktılardan biridir. Tam bilgi karar vericinin belirlenen karar durumlarının hangisinin olacağını tam olarak bilmesi durumunda seçeceği karar seçeneklerinin değerlerinin olay olasılıkları ile çarpılması ile bulunmaktadır. Tam bilgi ile beklenen kazanç 2.337 .500 € olarak bulunmuştur. Beklenen değer analizinde elde edilen beklenen değer ise 2.295.00 € kazanç değeridir. Tam bilginin beklenen değeri ise bu iki analiz çıktısının birbirinden farkıdır. Bunun sonucunda tam bilginin beklenen değeri 42.500 € olarak karşımıza çıkmaktadır. Karar verici tam bilgiye 42.500 € bedel ödemek koşulu ile ulaşabilmektedir. Bu sayede hem daha çok kazanç elde edebilmekte hem de karar verme durumunda daha net olabilme avantajı sahip olmaktadır.

Tablo 6. Olayların olasılıklarının sayısal verilere dayanarak atandığı risk altında karar matrisi

\begin{tabular}{lcc} 
& İyi Hava Koşulları & Kötü Hava Koşulları \\
\hline Olasılıklar & 0,5 & 0,5 \\
\hline Zeytin & $2.380 .000 €$ & $1.487 .500 €$ \\
Ceviz & $2.550 .000 €$ & $1.275 .000 €$ \\
Kiralama & $500.000 €$ & $200.000 €$
\end{tabular}

Tablo 6'da sayısal verilere dayanarak olayların olasılıklarının belirlendiği risk altında karar verme durumunda oluşturulan karar matrisi yer almaktadır. Karar matrisindeki değerler belirsizlik altında karar verme durumunda olduğu gibi POM QM paket programına girilmiş ve çözdürülmüştür. 
Özcan, B., Özer, E.H., Uluslararası Doğu Anadolu Fen Mühendislik ve Tasarım Dergisi / International Journal of Eastern Anatolia Science Engineering and Design (IJEASED)

(2021) 3(1):257-281

Tablo 7. Sayısal olarak belirlenen olasılıklı risk altında karar analizi sonuçları

\begin{tabular}{|c|c|c|c|c|}
\hline & & İyi Hava & Kötü Hava & Beklenen Değer \\
\hline & Olasılıklar & 0,5 & 0,5 & \\
\hline \multirow{5}{*}{ 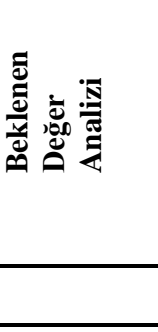 } & Zeytin & 1.190 .000 E & $743.750 €$ & $\underline{1.933 .750 \mathrm{E}}$ \\
\hline & Ceviz & 1.275 .000 E & $637.500 €$ & $1.912 .500 €$ \\
\hline & Kiralama & $250.000 €$ & $100.000 €$ & $350.000 €$ \\
\hline & & İyi Hava & Kötü Hava & $\begin{array}{c}\begin{array}{c}\text { Beklenen Firsat } \\
\text { Kaybı }\end{array} \\
\end{array}$ \\
\hline & Olasılıklar & 0,5 & 0,5 & \\
\hline \multirow{5}{*}{ 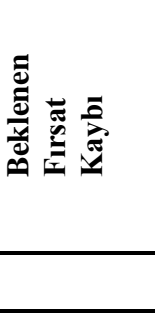 } & Zeytin & $170.000 €$ & $0 €$ & $\underline{85.000 \text { E }}$ \\
\hline & Ceviz & $0 €$ & $212.500 €$ & $106.250 €$ \\
\hline & Kiralama & $2.050 .000 €$ & $1.287 .500 €$ & $1.668 .750 €$ \\
\hline & & İyi Hava & Kötü Hava & Toplam \\
\hline & Olasılıklar & 0,8 & 0,2 & \\
\hline \multirow{7}{*}{ 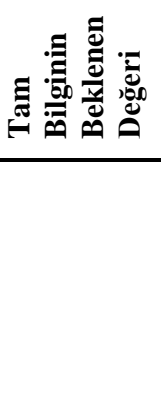 } & Zeytin & $2.380 .000 €$ & $1.487 .500 €$ & \\
\hline & Ceviz & $2.550 .000 €$ & $1.275 .000 €$ & \\
\hline & Kiralama & 500.000 € & $200.000 €$ & \\
\hline & Tam Bilgi & $2.550 .000 €$ & $1.487 .500 €$ & \\
\hline & Tam Bilgi (\%) & 1.275 .000 છ & $743.750 €$ & $2.018 .750 €$ \\
\hline & Beklenen Değer & & & $1.933 .750 €$ \\
\hline & $\begin{array}{c}\text { Tam Bilginin } \\
\text { Beklenen Değeri }\end{array}$ & & & $\underline{85.000 \text { E }}$ \\
\hline
\end{tabular}

Tablo 7'de görülen analiz sonuçları karar vericinin karar durumlarının gerçekleme olasılıklarının Tekirdağ ili 1938- 2018 yılları arsındaki aylık sıcaklık ortalamaları dikkate alınarak yapılması sonucu elde edilmiştir. Olasılıkların iyi ve kötü hava koşulları olan olaylar içerisinde 0,50'lik oranlar ile dağılması sonucu hem karar seçeneklerinin matris içerisindeki değerleri hem de analizler sonucu seçilmesi mantıklı olan seçenekte değişim gözlenmiştir. POM QM programı yardımı ile yapılan çözüm sonucu zeytin için beklenen değer 1.933.750 € ve araziyi kiralama durumunda beklenen değer ise 350.00 € elde edilmiştir. Beklenen değer analizine göre mantıklı olan ve karar vericiyi avantajlı duruma getirecek olan kazancı daha fazla olan zeytin karar seçeneği göze çarpmaktadır. Bir diğer analiz ölçütlerinden biri olan beklenen fursat kaybına göre zeytin için 85.000 €, ceviz için 106.250 モ ve kiralama seçeneği için 1.668.750 Đ kayıp değerleridir. Karar verici tam bilgi sahibi olması durumunda 2.018.750 £ kazanç değerine ulaşacağı Tablo 7'de görülmektedir. Tam bilginin beklenen değeri 85.000 € olarak bulunmuştur. 


\subsection{Karar Ăgacı}

Karar ağaçları, karar seçenekleri ve olay durumlarını bir arada ifade etmede kullanılan ve görsellik açısından karar verme durumlarını daha iyi ifade eden karar analizi şeklidir. Karar ağaçları düğümlerden ve dügümlerin gittiği yollardan oluşmaktadır. Karar ağaçları içerisinde yer alan bir öğe olan düğümler ise karar düğümleri ve olay düğümleri olmak üzere ikiye ayrılır. Karar düğümlerinden çıkan yollar yani arklarda karar seçenekleri yer alır ve olasılık bu arklarda yer almamaktadır. Olay düğümleri ise kendisinden sonra olayların ve olayların gerçekleşme olasılıklarının yer aldığı arkların geldiği düğümlerdir. Arklar ise düğümler arasında yer alan, karar ve olay düğümlerini birleştiren karar ağacı elamanıdır.

Araştırmada 12,5 dönüm tarım arazisinde yapacağı faaliyet hakkında karar verme amacı ile belirlenen karar seçenekleri 20 sene süre için değerlendirilmiştir. Arazide yapılacak olan faaliyetler 10 yıl tamamlandıktan sonra tekrardan değerlendirilip 10 yılın sonunda başlanan faaliyete devam edilip edilmeyeceğine tekrar karar verilmektedir. Değerlendirme yapılırken karar seçeneklerinin bağımlı olduğu karar durumları yani olaylar risk altında karar vermede olduğu gibi hem sezgisel olarak hem de sayısal olarak atanmış ve sonuçlar yorumlanmıştır.

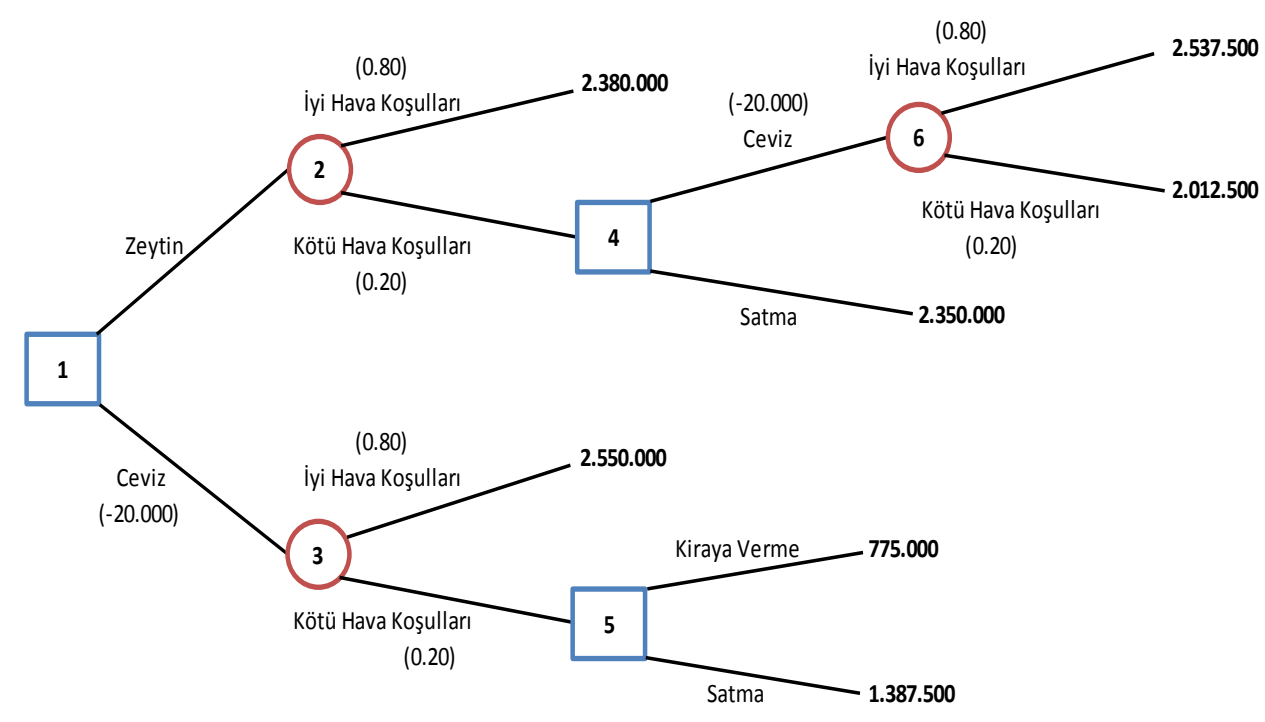

Şekil 1. Sezgisel olarak belirlenen olay olasılıklarına göre karar ağacı

Şekil 1'de görülen karar ağacı sezgisel olarak belirlenen olay olasılıklarına göre çizilmiştir. Karar ağacına göre karar verici yani tarım işleri ile uğraşan kişi arazisine ilk olarak zeytin ve ceviz faaliyetlerinden birisi ile başlamak istemektedir. İki seçenekte de karar verici 10 yıl faaliyetlere devam etmek istemektedir. Faaliyetlerin sürdürüldüğü 10 yılın sonunda tekrardan bir değerlendirme 
yapılmaktadır. Bu değerlendirmede karar vericiyi etkileyen faktör olaylardır. Olayların durumuna göre karar verici seçeneklerini tekrardan gözden geçirmek istemektedir. Karar verici zeytin seçeneğini 10 yıl sürdürmektedir. Sürecin sonunda olaylara bağlı olarak zeytini bırakıp ceviz seçeneğine ya da araziyi satma durumuna yönelebilir. Zeytin yetiştirme faaliyetinden ceviz yetiştirme faaliyetine geçerken 20.000 € ek bir maliyet ödemek zorunda kalacaktır ve 3 y1l boyunca araziden herhangi bir gelir elde edemeyecektir. Karar vericinin ilk olarak ceviz faaliyetini seçmesi durumunda ise yine bir 20.000 £ ek maliyet ve 3 yıl gelirsiz geçen bir süreç ile karşı karşıya kalacaktır. Ceviz yetiştirme 10 yıl devam edecek ve sürecin sonunda karar verici tekrar bir değerlendirme yapmaktadır. $\mathrm{Bu}$ değerlendirmenin sonunda ceviz yetiştirmeye devam edilebilir. Fakat koşullar kötüye giderse araziyi satma ve kiraya verme durumları değerlendirilir.

Karar ağacı tüm süreci özetleyecek şekilde oluşturulduktan sonra arazi sahibine fikir 1şığı olacak sonuçlara ihtiyaç duyulmaktadır. Bu aşamada karar ağacı POM QM programında çizilerek ve veriler girilerek oluşturulmuştur. Oluşturulan karar ağacı programda çözdürülmüş ve sonuçlar elde edilmişstir.

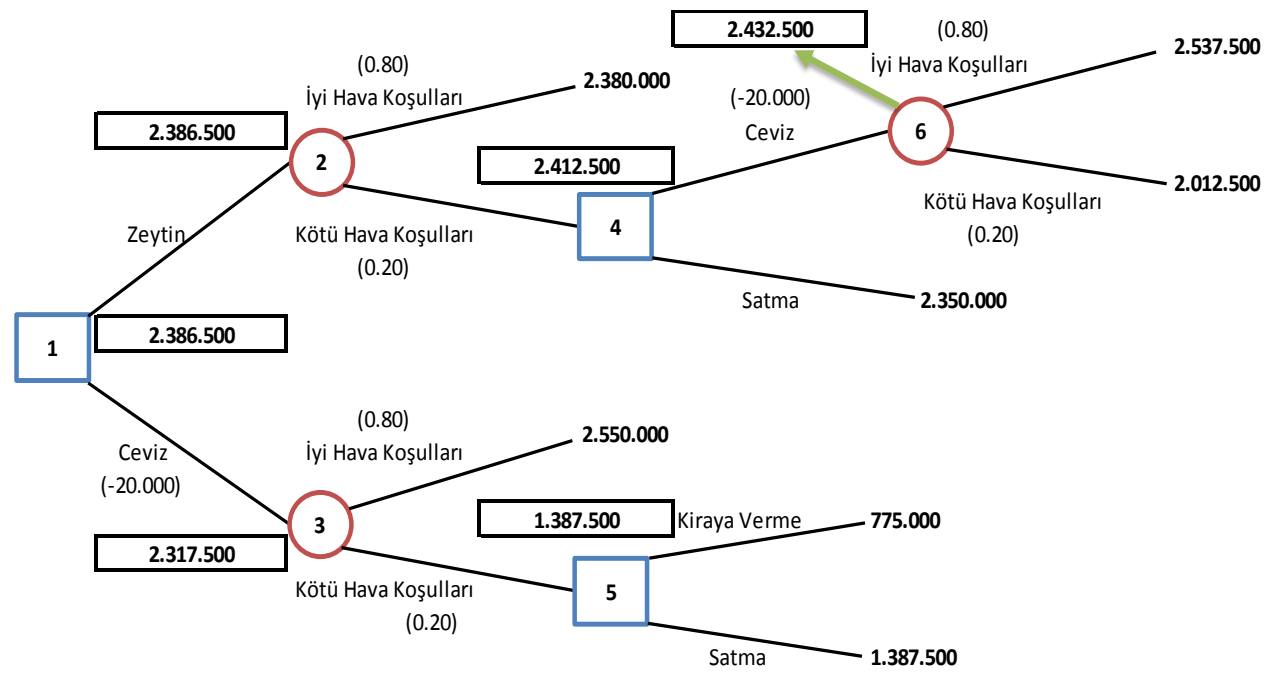

Şekil 2. Sezgisel olarak belirlenen olay olasılıklarına göre çizilen karar ağacının çözümlemesi

Oluşturulan karar ağacı POM QM programında Karar Analizi modülü kullanılarak çözdürülmüştür. Elde edilen sonuç Şekil 2'de görülmektedir. Şekil 2'ye göre 20 yıllık süre dikkate alınacak olursa karar vericinin zeytin yetiştirme faaliyetini seçmesi daha kazançlı bir durum oluşturmaktadır. Karar ağacı detaylı incelenecek olursa her karar ağacında olduğu gibi çözüme karar ağacının son düğümlerinden başlanmıştır. Düğümlerin beklenen değerleri tek tek hesaplanmıştır. İlk faaliyet olarak zeytin belirlenmiş olursa altıncı düğümün beklenen değeri bağlı olduğu olayların olasılıkları ile karar değerlerinin çarpılması sonucu büyük olan değer düğüm değerini oluşturmuştur. 
Dördüncü dügümün değeri ise ceviz yetiştirme faaliyeti ve satma durumundan büyük olan değer olan 2.412.500 ₹ değeri olmuştur. İkinci düğümün değeri ise olay olasılıklarının karar değerleri ile çarpılıp toplanması sonucu 2.386.500 ₹ olarak bulunmuştur. Karar vericinin hangi faaliyeti seçeceğini belirlemesi için İlk olarak ceviz yetiştirme faaliyetinden başlanılırsa beklenen değerin ne olacağ bulunmalıdır. Bu durumda zeytin seçeneğinde olduğu gibi son düğümden başa doğru çözümleme yapılmalıdır. Beşinci düğümün değeri kiralama ve satma seçeneklerinden daha yüksek değere sahip olandır. Bunun sonucunda 1.387.500 € kazanç değeri 5. düğümün beklenen değerini oluşturmuştur. Ceviz yetiştirme faaliyetinin beklenen değeri ise iyi ve kötü hava koşullarının olasılıkları ile karar değerlerinin çarpılıp toplanmış ve ek maliyet olan 20.000 € çıkarılmıştır. Elde edilen değer 2.297.500 モ gelir elde edileceği hesaplanmıştır. Karar ağacının ilk düğümünün değerinin 2. ve 3. Düğüm değerlerinden yüksek olanı yani zeytin yetiştirilmesi sonucunda beklenen değer 2.386.500 ₹ olarak bulunmuştur.

Karar ağacı çözümlemesi sonucu zeytin yetiştirme faaliyetinin daha mantıklı ve daha fazla kazanç sağladığı karar vericiye bir fikir sahibi olmasına ve arazisinin geleceği hakkında bilgiye sahip olmasına fayda sağlamıştır. Karar verici iyi ve kötü hava koşulu olmak üzere belirlenen olaylar karşısında 20 yıllık süreç içerisinde hangi faaliyetlerin ne gibi durumlarda öne çıtı̆̆ını karar ağacının çözümü ile görebilmektedir. Karar verici, karar ağacının çözümünden aşağıdaki bilgileri elde etmektedir.

Zeytin yetiştirme faaliyeti seçildikten sonra hava koşulları kötüye giderse ceviz yetiştirme faaliyetine geçmesi daha mantıklı olacaktır.

İlk olarak ceviz yetiştirme ile başlamak istenirse ve hava koşulları kötüye giderse 20 yıllık süreç için araziyi satmak daha fazla kazanç sağlamaktadır.

Arazi sahibi karar tercihini zeytin yetiştirmeden yana kullanırsa daha fazla gelir elde etmektedir.

Karar verici olasılıkların sezgisel olarak belirlenmesi ile elde edilen çözümden sonra olay olasılıkların sayısal verilere dayanarak belirlendiği bir çözümleme daha istemektedir. Oluşturulması planlanan karar ağacında olay olasılıkları Tekirdağ ilinin 1938- 2018 yılları arasında aylık sıcaklık ortalamaları dikkate alınarak atanmıştır. Atanan olasılıklar iyi ve kötü hava koşulları için birbirine eşit ve 0,5 olasılık değerleridir. Karar verici iki farklı yol ile belirlenen olasılık durumlarına göre değişimin olup olmayacağını bu şekilde görmüş olacaktır. 


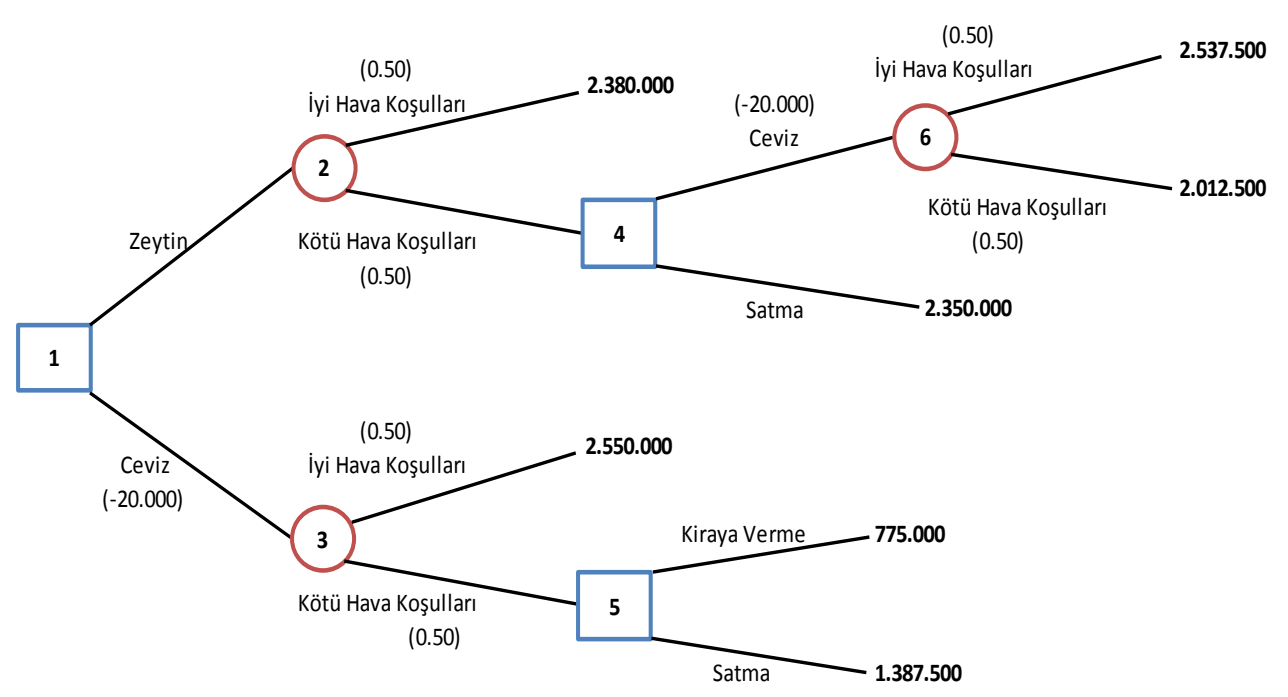

Şekil 3. Olasılıkların sayısal olarak belirlenmesine göre karar ağacı

İyi ve kötü hava koşulları aylık sıcaklık ortalamaları bazında hesaplanmış ve revize edilmiştir. Bunun sonucunda beklenen değer hesaplamaları yeniden yapılmıştır. Hesaplamalar yapıldıktan sonra sezgisel olarak alınan olay olasılıkları ile aynı seçenek tercih edilmiştir. Her iki durumda da zeytin seçeneği 20 y1llık planlama doğrultusunda mantıklı olan seçenek olarak bulunmuştur. Şekil 4'te 1 numaralı düğüm için beklenen değer olarak 2.365.000 ₹ bulunmuştur. Buradan hareketle olayların olasılıklarının belirlenme yöntemi değişmesine rağmen karar durumları karşısında seçilmesi mantıklı olan seçenek değişmemekte sonucuna varılır.

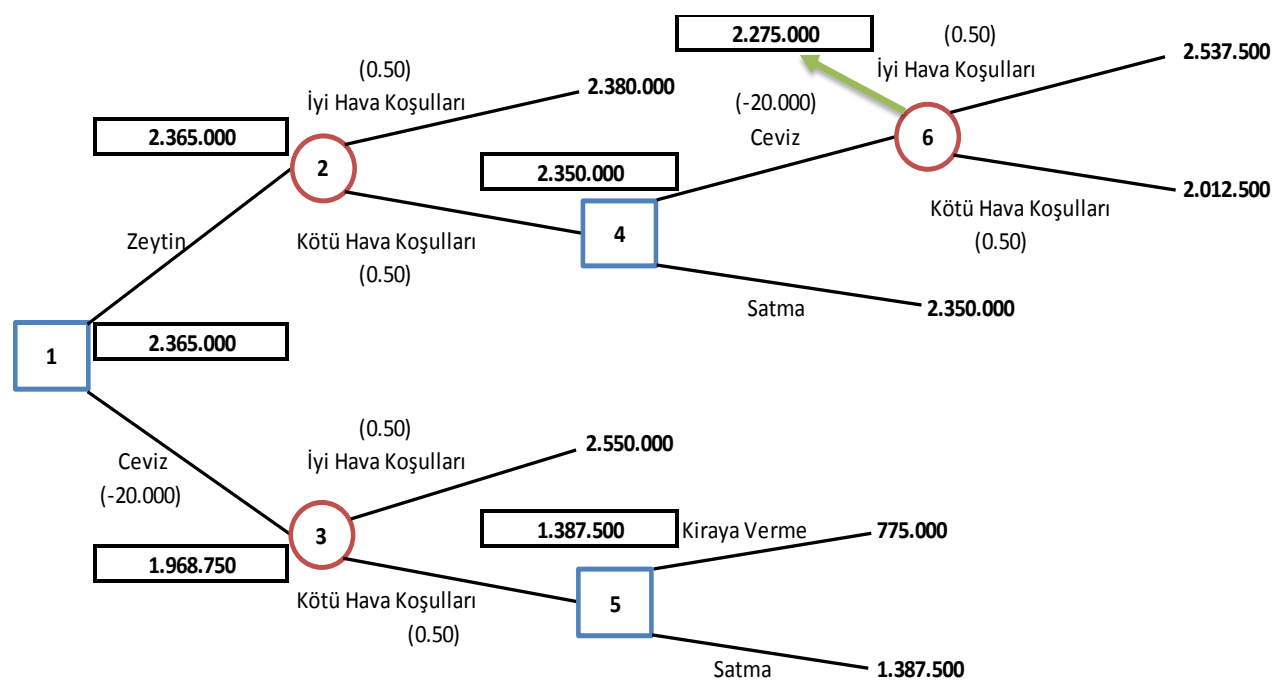

Şekil 4. Sayısal olarak belirlenen olay olasılıklarına göre çizilen karar ağacının çözümlemesi

Olayların olasılık değerleri sezgisel olarak ve sayısal verilere dayandırılmak üzere iki farklı yoldan yapılmıştır. İki durumda da zeytin seçeneği seçilmiştir. İki durumun farklılığı ise zeytin seçeneğinde 10 yıl boyunca kötü hava koşullarının olması durumunda seçilen karar seçeneklerinin 
farklılık göstermesidir. İlk durumda yani olasılık değerlerinin sezgisel olarak belirlenmesinde ceviz ekme seçeneği mantıklı seçenek olarak belirlenmiştir. İkinci durumda yani olayların olasılık değerlerinin aylık sıcaklık ortalamaları dikkate alınarak hesaplanmasında ise araziyi satma seçeneği beklenen değer olarak ceviz ekme seçeneğinden daha fazla getirisi olduğu için tercih edilen seçenek olmuştur.

\section{Sonuçlar ve Tartışma}

Tarım sektörü son yıllarda sanayinin gelişmesi ve sanayileşmeye verilen önemin artması sonucu bir düşüş yaşamaktadır. Sektörün ikinci planda kalması sonucu tarım işlerinde yapılan faaliyetlerin daha dikkatli gerçekleştirilmesini zorunlu kılmaktadır. Zeytin ve ceviz yetiştiriciliği de bu faaliyetlerdendir. Bu tarım ürünleri hakkında yapılan gözlem ve araştırmalar iki ağaç türünün de bir tarım ürünü ve kazanç sağlayan bir faaliyet olduğunu ortaya koymaktadır. Gerek ülkemizde yetiştirilme bakımından elverişli iklim ve toprak özelliklerinin olması gerek para kazandıran alanlar olmaları nedeniyle iki ürüne de yönelim gösterilmektedir. Tarım işleri ile uğraşan bireylerin kendileri için avantajlı ve ellerinde bulunan tarım arazisine uygun yetiştirme türünü seçmeleri son derece önemlidir.

Çalışmada tarım işleri ile uğraşan kişinin sahibi olduğu arazide yetiştirmeyi düşündüğü tarım ürünlerinin belirlenen karar durumlarına göre karar verici için daha mantıklı olduğu belirsizlik ve risk altında değerlendirilmiştir. Belirsizlik ve risk altında karar analizi yapıldıktan sonra görselleştirme açısından karar vericinin belirlediği karar seçenekleri ve olaylar karar ağacına yerleştirilmiştir. Karar durumlarının gerçekleşme olasılıkları sezgisel ve sayısal olmak üzere 2 farklı şekilde belirlenmiştir. $\mathrm{Bu}$ şekilde olayların olasılıkların belirlenme şekline göre karar vericinin tercihlerinde hangi değişimlerin olabileceğinin tespit edilmesi amaçlanmıştır. Belirsizlik altında karar analizinde iyimserlik, kötümserlik ve pişmanlık ölçütleri kullanılmıştır. İyimserlik ölçütüne göre ceviz, kötümserlik ve pişmanlık ölçütlerine göre ise zeytin yetiştiriciliği seçilmiştir. Risk altında karar analizinde beklenen değer, beklenen fırsat kaybı ölçütleri kullanılmış ve tam bilginin beklenen değeri hesaplanmıştır. Sezgisel olarak belirlenen olasılıklara göre beklenen değeri en yüksek ve beklenen fırsat kaybı en düşük olan seçenek ceviz olarak belirlenmiş ve tam bilginin beklenen değeri ise 42.500 olarak bulunmuştur. Sayısal olarak belirlenen olasılıklara göre ise zeytin seçeneği öne çıkmış ve tam bilginin beklenen değeri 85.000 olarak bulunmuştur. Karar ağacına göre de her iki durum görsele dökülmüş ve çözümlenmiştir. Her iki durum karşısında da karar verici için zeytin yetiştirme mantıklı ve daha fazla kazanç sağlayan karar seçeneği belirlenmiştir. İki durumun farklılığı ise zeytin 
Özcan, B., Özer, E.H., Uluslararası Doğu Anadolu Fen Mühendislik ve Tasarım Dergisi / International Journal of Eastern Anatolia Science Engineering and Design (IJEASED) (2021) 3(1):257-281

seçeneğinde 10 yıl boyunca kötü hava koşullarının olması durumunda seçilen karar seçeneklerinin farklılık göstermesidir. İlk durumda yani olasılık değerlerinin sezgisel olarak belirlenmesinde ceviz ekme seçeneği mantıklı seçenek olarak belirlenmiştir. İkinci durumda yani olayların olasılık değerlerinin aylık sıcaklık ortalamaları dikkate alınarak hesaplanmasında ise araziyi satma seçeneği beklenen değer olarak ceviz ekme seçeneğinden daha fazla getirisi olduğu için tercih edilen seçenek olmuştur.

Tarım arazilerinde gerçekleştirilecek olan faaliyet seçimi oldukça önemlidir. Tarım işleri doğaya bağımlı bir durumda olduğu ve koşulların sürekli değişim içerisinde yer alması nedeniyle belirsizlik ve riskleri içinde barındırmaktadır. Karar vericinin tarım işleri ile uğraşan bir kişi olması ve tarım sektöründe yönelebilecek faaliyetleri belirleme durumunda nasıl bir yol izlenmesi gerektiğinin açıklanması açısından bu çalışma önemlidir. Rastgele ve herhangi bir analiz yapılmadan yapılacak olan faaliyetlere girişmek büyük bir risk taşımaktadır. Uygulanması ve değerlendirme oldukça kolay olan karar analizi bu tip analizler için uygun olabilmektedir. Yapılan çalışmada konu alınan bölge dar bir alanı kapsamaktadır. Karar seçenekleri sınırlı sayıda belirlenmiştir. Çalışma küçük bir ilçe ile değil bir coğrafi bölge dikkate alınarak ve karar seçeneği ve olay sayısı arttırılarak daha kapsamlı ve veri bakımından daha kompleks bir çalışma ortaya çıkabilir.

\section{Kaynakça}

Akçetin, E. ve Çelik, U. (2014), İstenmeyen Elektronik Posta (Spam) Tespitinde Karar Ağacı Algoritmalarının Performans Kıyaslaması. Internet Uygulamaları ve Yönetimi Dergisi, 5(2), 43-56.

Albayrak, A. S. ve Yılmaz, Ş. K. (2009), Veri Madenciliği: Karar Ağacı Algoritmaları ve İMKB Verileri Üzerine Bir Uygulama. Süleyman Demirel Üniversitesi İktisadi ve İdari Bilimler Fakültesi Dergisi, 14(1), 31-52.

Arslan, S., Berkman, A. N. ve Doğan, Z. (2015), Türkiye'de Tarım Sektörünün İktisadi Gelişimi ve Sorunları: Tarihsel Bir Bakış. Niğde Üniversitesi İktisadi ve İdari Bilimler Fakültesi Dergisi, 8(1), 29-41.

Balçık, P. Y. ve Şahin, B. (2013), Sağlık Hizmetlerinde Maliyet Etkililik Analizi ve Karar Analizi. Hacettepe Sağlık İdaresi Dergisi, 6(2), 121-134.

Baykoç, Ö. F. ve Öz, E. (2004), Tedarikçi Seçimi Problemine Karar Teorisi Destekli Uzman Sistem Yaklaşımı. Gazi Üniversitesi Mimarlık Fakültesi Dergisi, 19(3), 275-286.

Bingöl, F., Değirmenci, S. ve Sofuoğlu, S. C. (2017), Türkiye'de Rüzgâr Arazilerinin Çok Kriterli Karar Analizi Kullanılarak Belirlenmesi, 4. İzmir Rüzgâr Sempozyumu, 27-32, İzmir.

Bulğurcu, B. K. ve Düzakın, E. (2011), Tarımsal Karar Analizi. Çukurova Üniversitesi Sosyal Bilimler Enstitüsü Dergisi, 20(3), 233-252. 
Ceylan, D. A. ve Sarı, F. (2017), Konya İli İçin Çok Ölçütlü Karar Analizleri ile En Uygun Arıcılık Yerlerinin Belirlenmesi. Uludă̆ Arıcılık Dergisi, 17(2), 59-71.

Çılbant, C., Yalçınkaya, H. ve Yalçınkaya, N. (2006), Avrupa Birliği’ne Yönelik Düzenlemeler Çerçevesinde Türk Tarım Politikaları ve Sektörün Geleceği Üzerine Etkisi. Yönetim ve Ekonomi, 13(2) ,97-118.

Emel, G. G. ve Taşkın, Ç. (2005), Veri Madenciliğinde Karar Ağaçları ve Bir Satış Analizi Uygulaması. Eskişehir Üniversitesi Sosyal Bilimler Dergisi, 6(2), 221-239.

Güzel, B. ve Taş, A. (2018), Tekstil Sektöründe Tersine Lojistik Sistemlerinin Tasarımlarını Etkileyen Kriterlere İlişkin Bir Karar Analizi. TMMOB Tekstil Mühendisleri Odası, 25(110), 154-168.

Mercan, Y., Sezgin, F., Ünal, H. B. ve Yılmaz, E. (2017), Tarımsal İşletme Yeri Seçiminde Coğrafi Bilgi Sistemi Destekli Çok Kriterli Karar Analizi Uygulamaları. Gaziosmanpaşa Bilimsel Araştırma Dergisi, 6(Özel Sayı-BSM-2017), 88-102.

Miran, B. ve Şahin, A. (2010), Risk Koşullarında Tarım İşletmelerinin Planlanması: Oyun Teorisi Yaklaşımı. Hayvansal Üretim Dergisi, 51(1), 31-39.

Özcan B ve Külahlı F. (2020), Lastik Sektöründe Karar Analizi Uygulaması, Uluslararası Batı Karadeniz Mühendislik ve Fen Bilimleri Dergisi, 2 (2), 28 - 54.

Özcan, B ve Yılmazer, E. (2020). Demir Çelik Sektöründe Yatırım Kararının Analitik Hiyerarşi Yöntemi (AHP) ile Analizi. Journal of Turkish Operations Management, 4 (2), 536-548.

URL-1, 2020. Tekirdağ Hava Durum Bilgisi, https://www.mgm.gov.tr, Ziyaret Tarihi: 03.05.2020.

Ulusoy, Gözde (2013), Karar Ă̆acı Analizi ile AB Genişleme Kriterlerinin Değerlendirilmesi. Yüksek Lisans Tezi, Marmara Üniversitesi Sosyal Bilimler Enstitüsü, İstanbul. 